\title{
Three Sections from a Novel, A Capitol Ship (in process)
}

\author{
Fielding Dawson
}

\section{GRAVITY}

We were playing guns, and I was hiding in some bushes by the barn in Steve's yard, when he crept up to me, and said, Hey, in low, tense words:

The Japanese have just bombed Pearl Harbor.

The Japanesel I cried.

He nodded. Dad called Mother from his office, and told her.

I said, But what does it I mean, why?

I don't know. Mom said Dad said President Roosevelt will go to Congress to ask for a declaration of war.

\section{JOHN HOOK AND THE PHILIPPINE YO-YO MAN}

We milled around on the sidewalk on Kirkwood Road in front of the dime store, watching the little Philippine man carving South Sea scenes on one yo-yo after another that kids, after having bought them inside, brought them outside so he could make his designs. For a dime.

But we were waiting for John Hook.

Inside the dime store, on the left side in the second aisle, yo-yos lay in piles in their respective price ranges: nickel size, dime size, and two-bit size. The nickel size was small, about two inches in diameter and chubby, one side black and the other red, in a matte finish. The dime size was larger, glossier and more thin. The two-bit size was tin, and had small holes, like portholes, along the edges of both sides, so when it got going it would sing.

Well, and the dime yo-yo was better than the nickel one, and the two-bit tin job was really neat, except that I liked wood and not metal, the singing didn't mean much to me, I could sing, and the Philippine man couldn't carve on tin, for sure, and in Kirkwood, Missouri, around 1942, to me, anyway, I gazed and gazed at the simple yet intricate scene he carved on my yo-yo, not so much because of the scene pictured, palm trees, and a sense of the horizon, though that too, but what touched me was his flickering fingers, and quick wrist-turns: how he did it.

For a nickel, or a dime I could have all that, plus the important fact that on the wooden yo-yos the thing was to gently undo both sides, wax the wooden axle, and loop the string around, replace the sides, and walk around town throwing endless circles, as the string had no grip and the yo-yo once got going, spun evenly at the end, and my red and black yo-yo spun at the farthest reach of the string without effort, or, on a straight down plumb line as I walked along, it spun and slept at the end of its string; at the risk of chipping it, and marring the scene of the South Seas, I let it walk, on the sidewalk beside me down Kirkwood Road. 
John Hook walked toward us.

He had a gait, he had a muscular build, a head like a box with a cowlick and a monkey face with a big mouth and white animal teeth and a wild twinkle in his big bug eyes and he could steal anything, which delighted me as I generally was the one who kept us supplied with comic books, candy, and cigarettes, stolen from not too careful Irish Catholic store owners - we were all Episcopal and John, who enjoyed stealing, and was especially fond of lifting yo-yos, was one of those marginal midwest church members maybe Baptist or something that nobody Protestant ever knew anything about except that they continually had good pitching in the church softball league.

On sight of John, rolling along toward us, we began to laugh, and when he joined us, we put our arms around each other and moved out of vision around from the large plate glass dime store windows back into the alley and made our plans; hardly coherent. We talked about money.

John outlined the action we knew by heart anyway, but it was to hear him and watch him that was the thrill of before action, and in delight's envy, of a certain overflow willingness: point in my character that caused me to overlook everything in my passion to do it right and then do it again just to make sure, yet, as John being John, the thrill to make my head spin, was to do one thing once so completely it included any following flourish, no reassurance with him and that was John: the neat flourish to begin with, because when John Hook showed up, he completed the action we had begun by waiting for him, because he could hook anything, his last name was not Hook and it was me who named him in my crystal Missouri laughter and when I went in the dime store with my nickel in my hand, and made a purchase and so distracted the salesgirl, I was aware of the fleeting sunshine shadow behind me moving down the aisle to my left selecting yo-yos, my breath came fast in no way was I cool: my eyes were so bright I feared, like in love they'd give me away, I mean there he was right there, that Robert Louis Stevenson thief in the aisle choosing the best as I completed my purchase and in a signal whistle, I left, as the Hook shadow melted outside onto the sidewalk.

Into the alley: we tumbled in laughter, as John showed us what he'd hooked, and our eyes lit up as he distributed them around, and in a rising chill that caused me such delight I fielded an invisible grounder over second, made the pivot, stepped on the bag and threw to first for the double play, we calmly walked back out onto the street to the Philippine yo-yo artist, who, with a few kids around him, surely caught our aura, and folding and putting his knife in his pocket, in answer to our requests, rose and did a few tricks with a yo-yo that made us gape and breathe the air stood still for his yo-yo could sleep as if forever no matter where it went, and he made it walk, and sing, and go around the world, and rock the cradle with such ease and skill that in his alien visage caused us and surely me, especially me, to not only so much wonder at the control of the yo-yo so wonderfully, but to want to be the man who could do it.

He sat, poker faced and intense in effort, slightly bent on his little folding chair on Kirkwood Road, beside me, as traffic went its way like adults: un- 
noticed, and I intently bent as he began to carve with his knife, on my nickel yo-yo, as my pals breathed down my neck, watching his thin brown wrist and fingers skillfully carving the trunk of the palm tree, then a coconut, the palm leaves, and then the horizon in a sort of ripple he carved my name. At once the water, a world toward China in a vision of distant lands beyond, I saw the tiny curlicues of wood as he blew them away, and the neat flowing cuts in the wood, and my dilated eyes saw the wood in my name and trees showing out from the matte paint, and as he handed it to me and I gave him his dime he made a curt nod, and in a glance raised his eyes to see who was next, as the kids pushed and shoved, and I, greed satiated in his transient's blank gaze, backed away and studied my prize. We all compared our yo-yos, and I, staring at my name, was the real thief, or if I could be, I would, to steal and be him, as we walked away, went down Argonne Drive, in a divided magic with John, to the grass alongside the Missouri Pacific railroad tracks, where I took my yo-yo apart carefully, and fixed it so it could sleep.

\section{UNCLE CHARLEY}

When my Uncle Charley came to visit, he came whirling in touching everyone in his path, beginning when his old banged up mud splattered truck, which squeaked and shuddered, jolted to a stop by the bushes at the end of the front walk. And his thin wife Eloise with the baby girl Serena in her arms, climbed out of the front seat, and Charley himself angled out from behind the wheel, yelling at his other three daughters in back, who from behind slatted side braces, peeped and steadily gazed at the house where I lived. Betty, the oldest and my age; Cathy next, a couple of years younger, and Mary Lou, a couple of years younger than that though a few years in front of Serena, and they all climbed out of the back of the truck, and laughing shyly, walked big-eyed up the walk behind their Father and Mother, all of them poorly dressed, and in their different faces were as clear to me as a birthday in August. An invasion force, fresh in from the farm.

They thundered up the front steps, the three girls almost blushing with curiosity, but to me they were also a threat, they came through my self-fog as if they didn't see it, or even their own fog, and our house shifted and shook when Charley banged on the front door, opened it himself, and came in shouting, he had a natural shout, and a special greeting: his voice jumped around books, paintings, the upright piano and horsehair stuffed furniture in my Victorian house DARATHY! KERRA! MARY! KATE! MILDRED! ESSEX! I'M HERE WITH ELOISE AND THE GIRLS -

Aunty Mil - Why it's Charley!

Aunty Katy, putting down The Saturday Evening Post, and with an effort, rising from the pillows on the swing in the little screened-in cabin, covered with morning glories in the back of the main house, saying, to herself softly, in the thunder of feet and murmurs gee whiz, Daddy? golly, boy!

Well, I'd better get Mary to make some sandwiches. Charley's here.

As she left the little building, I heard Mother say, 
Dorothy, Charley's here - with Eloise and the kids.

Oh. Good! Dorothy cried. I wasn't sure it would be today.

Mother and Aunty Dot came downstairs just behind Mildred, Mother saying, We'd better get Mary to make some sandwiches. The kids will be hungry.

Aunty Mary was on her hands and knees in the garden, in among the roses, in fact, pulling weeds, and Aunty Katy crossed the back lawn, and when she was just behind her sister, called - loud, 'cause Aunty Mary was deaf,

MARY! CHARLEY'S HERE WITH ELOISE AND THE KIDS!

Aunty Mary went on pulling weeds.

MARY!

She had unplugged her hearing aid. Katy tapped her on the shoulder

- MARY!

Aunty Mary looked up, startled, and Aunty Katy said, patiently, as Aunty Mary fiddled with the hearing device,

Mary, Charley's here with Eloise and the kids, come in and make some sandwiches!

Aunty Mary's face was puzzled as she got all the parts connected and tuned up and in, and then she looked up, making little sounds in her throat, she had a guitar in her throat, and with a warm expression and bright eyes, she said,

Charley's here?

Katy smiled and nodded, and said something about sandwiches; Aunty Mary's face clouded, but then she exclaimed:

I'll heat up last night's soup - hmp there's some left over!

Mother appeared on the porch, and called across the lawn to Aunty Katy,

Kay, Charley's here with Eloise and the kids. Tell Mary to come in and make some sandwiches. They'll probably be hungry.

Aunty Katy's face darkened, and she said,

I know that and that's what I'm doing! Tell Charley we'll be in, in a minute.

Mother's face darkened too, and her eyes got a little chilly, and she said, well,

Well, he's here. That's where I got that from.

I snuck around the back of the house, went by the cistern and through the back door into my room, up two steps into and along the small back hallway passing the bathroom, turned left, went through the library and into the living room; I stood behind the glaze in the glass doors, in the doorway by the upright piano, and watched all my aunts and Mother embrace their brother, his wife and three daughters plus a baby that could hardly see, in front of me, the words and sounds loaded with affection and kindness, and I frowned because it made no sense at all, so I smiled. My eyes met hers.

Hi! Cuz Fee, called Cathy, big grin. Then she blushed.

I grinned. Cuz Fee. As I made a small return my heart jumped, seeing her well ordered nervous reckless enthusiasm under dark brown bangs, and with her heavy eyebrows, and her dark flashing eyes right on mine she lowered them quickly, down along her turned up nose, making still her red lips, in a glint of two big radish white teeth, and I trembled in my tracks. As the Uncle Charley tornado whirled by, missing me, and settled noisily in the living room. I faded 
around the doorjamb into the front hall where they had been standing, and as they moved into the living room, I said, with a half fake smile and my eyes betraying me as I glanced at my magic cousin Cathy, in my curiosity,

$\mathrm{Hi}$, Aunt Eloise.

In the shifting crowd she seemed to turn four ways at once, but then, recognizing me, made a crooked typical smile and discovered herself, and said hello. Then she went into the living room, and sat down nervously, and looked through her round steel-rimmed glasses, out and around the room, at everybody talking at once except her three daughters, who sat with their knees together, their feet apart and their hands in their laps; with hardly a glance at anyone Eloise asked, in a shy smiling voice, politely, with a caw in it:

Could ah mm have a cup of coffee?

Fee dear, Mother said royally, go out and help Mary, would you? Tell her to make coffee for all of us. Except.

Charley, snapped Aunty Katy.

Suddenly Aunty Mary ran into the living room wiping her hands on her apron saying coffee'll be ready in a minute and so $\mathrm{hmp}$ will the sandwiches, and she sat down at the piano, and began to play and sing a song she had written from Grandfather's poems, each line ending with the same three words, all (with a lift), pause, so (dipping) gaaayyy, and the last line ending like the others, but going up: all (lift), so (higher), (highest) gaaayyy!

Everyone generally patted their hands, and then Mother, Katy, Mildred, Dorothy, Charley, Eloise and the kids, erupted into talk and laughter as Aunty Mary rose, and laughing explained it all to us, about Papa's poetry, and how she had, etc., we all knew it, especially Papa, etc., through her, with a big smile that meant she saw herself before all of us, and in a confused flurry turned and went through the front hall into the dining room and then into the kitchen and began bouncing cups and saucers around, with silverware, on a tin tray.

I had been leaning on the doorjamb, and was about to go into the kitchen to help, when I heard the front door open. I turned, and my sister came in, out of breath and brightly laughing -

I saw the truck! Uncle Charley's here!

We laughed.

I watched her as she went into the living room, like somebody you wait for, delightfully opening windows she approached him saying Oh Uncle Charley, how swell to see you!

Then she burst into laughter because Uncle Charley, who had been yelling at Dorothy hardly noticed, and then he did, and was brusque in his embrace, and kiss, and as she pulled up a chair beside him he began to shout about the prices, crops, the war and bad luck. I went into the kitchen. Jesus.

Aunty Mary was making her usual gruesome peanut butter sandwiches. Slapped a blob of the oleo I had mixed onto a slice of white bread, slapped a blob of hard dry peanut butter in the center of another slice and clapped 'em together, singing, All so gaaayyy! Aunty Mary:

LET ME DO IT! 
$I$ can do it, she complained.

No, you CAN'T! I shouted.

Yes I can hmp, get coffee cups saucers napkins on the tray the water's boiling, the jay birds are back! Get the Postum for Charley!

Making peanut butter sandwiches was something I could really do. The ones she made the bread would tear, and she didn't care. They would know. I went tense in anger.

Please, Aunty Mary. Let me make them!

Blam! another one and she thrust me to one side saying No! mp Nol Load the tray!

I did, and then I walked out of the kitchen, and went down the back hallway into my room, walked in a couple of circles and everything seemed distracted, so I went outside and down the back driveway which curved around our nextdoor neighbor's house and out onto the street, where I walked North to Matthew's Field where we all played, but nobody was there, and I walked along under the apple trees to the barn at the end of the field, and watched the Matthews' farmer Gus at work, following him around, watching him work, which he was used to; he rarely said anything, to anybody, although he spoke to himself, under his breath, he was an old man, big and stooped from carrying pails of sweet milk all his life, and he wore the same kind of farmer's overalls that Uncle Charley did, with the straps. I had worn them too, in Muddy Run, in Pennsylvania. We all liked Gus, and in his way I guess Gus liked us too, occasionally we helped him, get something for him, you know, he let us alone, he thought we were crazy, and we never teased him 'cause he moved fast when he wanted, and well there was a way the cows looked at him; they knew, and cows can move fast when they want to, too, but Gus wore a large sweat-stained floppy hat, and though he was a patient old man, when a cow got extra stubborn Gus's eyes got extra hard, and after he had finally gotten the cow into the barn and the cow wouldn't go in her stall, Gus's eyes kind of glowed out from under the brim of his hat, and the two of them stood there in hay and a little cowshit looking at each other, the cow getting that look they have when they're making it a little tougher than usual, an onrey straight-on look, and old Gus stood there and looked right on back at her, her with her big brown eyes, and he raised his hand and pointed into the stall, and in his gruff quiet way ordered her in, and she didn't move.

"Go on," he said. "You know the way." Then he laughed to himself, and I stood behind him, breathless.

She swung her tail, lowered her head and pretended to look around for something on the floor, and went into the stall.

He turned, and glanced at me, one eye from under a shaggy eyebrow and I grinned and he nodded as I turned and walked back outside. He didn't like anyone around when he milked. I went along the edge of the field and picked an apple, they were green, but I didn't mind, I ate one, and as there were several on the ground that were half rotten, I got a bunch and walked away from the tree, into the field, where I stopped, dropped the apples on the grass, 
and fixing the spot on the tree trunk where the second baseman's glove would be, I backed up a little, and then ran in, scooped up an apple, and fired to second for the out, and when I got tired of that I practised my outfield throw, and partly worn out and partly in my fog-state, I ambled back to the barn, and Gus was standing in the doorway lighting his dime store corncob, and I watched him. When he got it lit he pointed the stem at the apple in my hand and tossed away the match stick, and shook his head a little, and said, Ye keep eatin' them green apples ye'll get the shits, and I began to laugh, I leaned against the barn holding my stomach I was laughing so hard, the cussword from him, and he shook his head, puffed on his pipe, turned and went back inside the barn. I heard him going up the steps into the hayloft.

I went home, and on the way I caught sight of the O in the STOP sign on the corner, I dropped the apple, and as it made a crooked bounce I yelled,

"The SHITS!"

recovered it, and threw with all my strength and missed. But I hit the sign. So, even so, he could have fielded it.

I walked home smelling the apple on my breath, and fingers, and in pure sensation I missed seeing Uncle Charley's truck make a U-turn, and head back the way he came, with the girls in the back waving to me and crying my name. Then I saw it, and I waved back, guiltily and sadly, feeling a little lonely. I looked up at the sky as his truck got to the corner at the top of the hill, and after stopping for a moment, went on its way.

The sun was in its place, in the afternoon, and just to check up on myself, I figured I'd take a look at the sun dial, even though I knew what it would say, but I loved the feeling of being right, so I did. I cut across the front yard and went around in back, where Aunty Mary had been in the rose patch, and passing the slab-concrete bench, I stood by the silent sun dial, looking downward at the back-slanting triangle, set vertically on the disc which was embedded in the four foot high miniature Corinthian cement pillar. The triangle and the disc were beautifully mottled: green bronze, and the projected razor-edged shadow, rested neatly there between the Roman numeral 4 , and 5 which in spite of daylight savings the sun had already told me.

One afternoon I came home from school, and there was Uncle Charley's truck, parked on a tilt in its place by the bushes at the end of the front walk, and letting curiosity in, me and my fog went up the walk into the house where I saw him in the living room with my Aunt Dorothy (Dorf), talking loudly about crops, the prices, the war, and bad luck. 
I saw my sister in a chair in the corner, half silhouetted against the front window, and for a second I thought it was Mother smoking a cigarette. Uncle Charley's voice was tense.

I went in quietly, put my books on top of the piano, and sat down on the piano bench, and listened.

I KNOW, he shouted, AND GODDAMNIT I DO -

Charley -

WELL I DO KNOW, DOROTHY, AND I'M TELLING YOU IT'S BAD, I CAN'T SEEM TO DO ANYTHING RIGHT AND NOTHING SEEMS SET UP FOR ME TO DO RIGHT, D’YA UNDERSTAND?

We nodded.

He stood up and paced the floor in his faded work shirt, worn, dirty overalls, and worn thin-soled shoes; his face was haggard and tired, but gaunt, angry, and wild and I watched him as he reached into his pocket with one hand and pulled out a three fingered clump of raw tobacco, and with the other hand a cigarette paper, and as he paced the floor he rolled a cigarette dropping most of the tobacco on the rug. Aunty Dot said, Really Charley and then laughed, and so did my sister and so did I, and he said loudly, he wanted another cup of coffee and not Postum, and raising the cup from the table, finished it, and as he put it back in its saucer on the table, he staggered to his left, regained himself, and Aunty Dorf said,

No, Charley. You know what it does to you!

He threw his hands in the air, and waving his arms walked crazily around the room, shouting and grumbling, as she said,

Why don't you rest a while in Mouse and Fee's room - then she laughed.

He did too, and yelled,

DO YOU THINK A NAP IS WHAT I NEED?

Well, you're tired and upset.

A few minutes later, when I was in the kitchen drinking some milk, I heard Dorf say, here

Take this, Charley dear.

His responding voice was hushed in humility; honest. But strange, like at the theatre. Thanks Dot, you've been wonderful.

Well, we love you and want to help.

I know you do. I love you too. It means a lot.

Goodbye, dear, she murmured.

Goodbye, Dot. I'll call you next week. Love to the girls -

Yes, of course, and our love to Eloise and the children.

Soft sound of door opening and closing. I stood in the kitchen still hearing the direct clear words. I didn't know they existed, like that. In our house.

My sister came into the kitchen, and seeing me, paused in the doorway. Our eyes met, and she said, grimly,

Boy, I love that man.

I nodded. Me too.

Her name was the same as Mother's: Cara, except everybody called my sister 
Cara Junior, which she hated. That was probably my romantic Father's idea, he was so in love with his wife he named his only daughter after her. Mother, impressed but shy, agreed. Who could argue with love?

In those days.

In 1925.

In New York.

We'd all gone out to Uncle Charley's farm for a visit. He lived in Hillsboro, Missouri, a gasoline station post office grocery and feed store town, and the road up to Charley's farm went up the side of a hill that was so steep we only drove half way, and then got out and walked the rest.

His farm was right on top; crops were overgrown with weeds, and he couldn't get anybody to help him because he didn't have any money and even if he had, all the men were in the war. He had one man who helped, an old black man who stayed around because there was no place else to go.

My sister and me went for a walk.

We held hands and went through grass gone to seed; we ate grapes, and picked blueberries, and flowers, watched bees gather honey, and we chewed the stems of sweetgrass, and looked out along the wonderful view of the hills and valleys in the four directions under the blue midwestern sky, where an occasional puff of cloud drifted idly by, and alone.

She said, suddenly, Look - she knelt at the base of a post where the grapes sagged on wild vines, and where the shaft entered the earth, in sienna she parted long ripe brilliant green blades of grass, and revealed violets, and I bent, then knelt beside her and we gazed into that tiny little shady corner of the universe letting our cheeks graze under our tender awe, words flowing on our breath Gee whiz they're beautiful, in perfume of earth, grapes, grass, and violets. She let the blades of grass return as they had been, and we rose and returned to Uncle Charley's farmhouse, with its broken furniture, bent utensils, and a despair that likened to that cracked and bare knuckled poverty we had seen in Florida, Pittsburgh, the mountains of Pennsylvania, and the places along the way to Missouri through the 'Thirties where the poor people stood in the dust with their empty hands, and drawn faces, by gas stations, bus depots and post offices or by the sides of the roads all across America in that soft and invisible, vehement slow footed move to the horizon. The people. The poor. The people at which my sister and me stared, silently, sadly, in our journey to Kirkwood, Missouri, for a place to live, while our Father tried to find a job in New York, and everybody stared at the horizon. Then. And in 1941 our Father came home to die. And on top of a hill it turned into Uncle Charley's sagging and broken corncrib which fed only the rats, against the future placed in my memory not to ever leave.

I sat in the front seat of the car beside my Uncle Mouse (Essex), and when we had begun to drive home, leaving Hillsboro he glanced at me, and said,

You're awful quiet today. What's the matter?

I laughed, and turning in the seat so I could look at him, I asked, Uncle Charley's really poor, isn't he? 
Yeah, he said, as the car swung onto Highway 66; and Eloise and the kids think we're rich. 